\title{
Analisis Pengaruh Brand Awareness dan Brand Image terhadap Keputusan Pembelian Busana Muslim Merek Rabbani di Kota Jambi
}

\author{
Rafidah, Bambang Kurniawan, Khalida Zia \\ Fakultas Ekonomi dan Bisnis Islam UIN Sulthan Thaha Saifuddin Jambi \\ email: rafidah_haris@yahoo.com
}

\begin{abstract}
Abstrak : Penelitian ini bertujuan untuk mengetahui pengaruh Brand Awareness dan Brand Image secara parsial dan simultan terhadap Keputusan Pembelian pada busana muslim merek Rabbani di Kota Jambi. Jenis data yang digunakan dalam penelitian ini adalah data primer. Pengumpulan data dengan cara angket (kuesioner), observasi, wawancara dan dokumentasi. Sampel dalam penelitian ini berjumlah 100 orang. Analisis data yang digunakan adalah analisis deskriptif, uji validitas, uji reliabilitas, uji asumsi klasik, analisis regresi linier berganda, uji $\mathrm{T}$, uji $\mathrm{F}$ dan analisis koefisien determinasi. Penelitian dilakukan dengan persamaan regresi linier berganda untuk pengaruh brand awareness dan brand image secara bersamaan terhadap keputusan pembelian pada busana muslim merek Rabbani di Kota Jambi adalah $\mathrm{Y}=4,849+0,281\left(\mathrm{X}_{1}\right)+0,414\left(\mathrm{X}_{2}\right)+$ e. Brand awareness berpengaruh signifikan terhadap keputusan pembelian karena nilai $t_{\text {hitung }}>t_{\text {tabel }}$ atau 3,117 $>1,984$ dan nilai signifikan yang dihasilkan 0,002 < 0,005. Brand image berpengaruh signifikan terhadap keputusan pembelian karena nilai $t_{\text {hitung }}>t_{\text {tabel }}$ atau 4,487 $>1,984$ dan nilai signifikan yang dihasilkan $0,000<0,005$. Nilai koefisien determinasi adalah 0,391 nilai Keputusan Pembelian (Y) dipengaruhi oleh Brand Awareness $\left(\mathrm{X}_{1}\right)$ dan Brand Image $\left(\mathrm{X}_{2}\right)$ sebesar 39,1\%. Sedangkan sisanya sebesar $60,9 \%$ nilai keputusan pembelian dipengaruhi oleh variabel lainnya yang tidak diteliti dalam penelitian ini.
\end{abstract}

Kata-kata kunci : Brand Awareness, Brand Image dan Keputusan Pembelian

\section{Pendahuluan}

Mayoritas penduduk Indonesia menganut agama islam, dengan latar belakang ini menjadikan kebutuhan akan pakaian muslim sangat tinggi dan sangat menjadi prioritas utama bagi para kaum muslimah. Dalam hal ini diiringi dengan perkembangan pakaian muslim yang semakin beragam, dan menjadi sebuah kesempatan untuk para produsen pakaian muslim untuk selalu menciptakan inovasi fashion muslim secara terus-menerus. ${ }^{1}$

Kota jambi merupakan salah satu kota yang banyak bermunculan ritel-ritel bisnis khusus menjual busana muslim. Banyaknya ritel busana muslim di Kota Jambi yang memberikan kesempatan bagi para konsumen menjadi pelanggan tetap. Masyarakat muslim Kota Jambi telah mengenal trend model pakaian busana muslim,

${ }^{1}$ Ayu Lestari, Pengaruh Harga dan Produk Terhadap Keputusan Membeli Produk Elzatta (Studi Kasus pada Mahasiswa UIN Raden Fatah Fakultas Ekonomi dan Bisnis Islam), (Palembang: UIN Raden Fatah, 2016). Hlm. 1 
dari perubahan gaya hidup dan kemajuan zaman tersebut yang telah mengangkat busana muslim menjadi trend di kalangan masyarakat muslim Kota Jambi.

Rabbani merupakan salah satu merek busana muslim. Rabbani termasuk perusahaan garment yang bergerak dalam bidang ritel busana muslim dengan tagline professor kerudung Indonesia. Rabbani merupakan salah satu perusahaan kerudung instan pertama dan terbesar di Indonesia dengan mengeluarkan produk andalan berupa kerudung instan. Selain kerudung instan, produk lainnya juga telah dikembangkan yaitu busana muslim, diantaranya dresslim, kemko, tunik, kastun, serta perlengkapan lainnya seperti ciput atau inner kerudung, serta aksesoris. ${ }^{2}$

Rabbani yang berada di Kota Jambi merupakan cabang Rabbani yang berpusat di Bandung, Jawa Barat. Rabbani memiliki segmen pasar umat Islam baik itu laki-laki maupun perempuan. Saat ini Rabbani memiliki 154 reshare atau cabang yang tersebar di seluruh Indonesia dan luar negeri. Rabbani termasuk pemasar busana muslim terbesar di seluruh Indonesia. Dari situlah Rabbani memperoleh penghargaan sebagai merek busana muslim terpopuler. Hal tersebut merupakan suatu kelebihan yang dimiliki oleh Rabbani. ${ }^{3}$

Dengan membuka cabang di Kota Jambi menandakan bahwa Rabbani melakukan perluasan pasarnya di kota-kota besar khususnya di Kota Jambi. Kemunculannya jelas membuat persaingan toko busana muslim di wilayah Kota Jambi semakin ketat. Kondisi persaingan yang ketat tersebut bisa ditunjukkan oleh adanya beberapa toko busana muslim lainnya yang berada di Kota Jambi, tetapi Rabbani juga tidak kalah bersaing, sebab sudah memiliki merek tersendiri, sehingga namanya juga dikenal oleh masyarakat di seluruh Indonesia.

Setiap produk yang memiliki brand atau merek memiliki nilai yang sangat berbeda dengan produk yang tidak memiliki merek. Dalam hal ini tentunya merek mempunyai fungsi sebagai alat promosi, sehingga mempromosikan hasil produksinya cukup dengan menyebutkan mereknya. Selain itu merek sebagai jaminan atas mutu barangnya. Hal ini dapat menunjukkan asal barang atau jasa yang dihasilkan bernilai sangat penting karena merek selain sebagai identitas perusahaan dan sebagai alat promosi barang atau jasa terhadap konsumen, merek juga dinilai dapat membangun kesadaran atau kepekaan bagi konsumen terhadap produk tertentu. ${ }^{4}$

Menurut Keller dalam Chandra brand awareness merupakan kemampuan merek untuk muncul dalam benak konsumen ketika merasa sedang memikirkan produk tertentu dan seberapa mudahnya nama tersebut dimunculkan. Kesadaran merek dapat ditimbulkan melalui penggunaan nama merek itu sendiri, logo, kemasan dan slogan yang digunakan sebuah perusahaan dalam rangka mengenalkan atau menginformasikan produknya. Brand awareness dapat mempengaruhi dengan memberikan informasi dan kekuatan dari pendekatan yang dapat meningkatkan

\footnotetext{
${ }^{2}$ Mita Yuniati, Faktor-Faktor yang Mempengaruhi Minat Konsumen Terhadap Produk Rabbani, (Surabaya: Universitas Negeri Surabaya, 2013). Hlm. 85.

${ }^{3}$ Indra Lesmana, Pengaruh Ekuitas Merek Terhadap Keputusan Pembelian pada Rabbani Dipatiukur Bandung, (Bandung: Universitas Komputer Indonesia, 2014). Hlm 2.

${ }^{4}$ Risky Chandra, Pengaruh Kesadaran Merek dan Citra Merek Terhadap Minat Pembelian Sepatu Merek Under Armour di Bandar Lampung, (Bandar Lampung: Universitas Lampung, 2015). Hlm 1.
} 
brand image atau citra merek. Dalam meningkatkan brand awareness dapat pula meningkatkan kemungkinan bahwa merek tersebut akan menjadi pertimbangan keputusan pembelian bagi konsumen, bahkan diantara beberapa merek tersebut akan mendapat pertimbangan yang serius untuk keputusan pembelian bagi konsumen karena tingkat kesadaran yang kuat. ${ }^{5}$

Menurut Tjiptono dalam Supriyadi, "Brand Image merupakan deskripsi tentang asosiasi dan keyakinan konsumen terhadap merek tertentu". Brand image itu sendiri memiliki arti kepada suatu pencitraan sebuah produk dibenak konsumen secara massal. Setiap orang akan memiliki pencitraan yang sama terhadap sebuah merek. Persaingan dunia industri yang semakin ketat saat ini, menuntut perusahaan untuk lebih kreatif dan membuat suatu keunggulan yang kompetitif, baik itu dari segi kemasan, produk, saluran pemasaran maupun citranya, jika tanggapan konsumen tentang penawaran suatu produk yang bersaing tetap seabgai suatu hal yang sama atau biasa, maka konsumen akan melihat merek dari suatu produk dengan tanggapan yang berbeda. ${ }^{6}$

Tetapi apakah Brand Awareness dan Brand Image pada busana muslim merek Rabbani masih berpengaruh terhadap keputusan pembelian konsumen, karena jika Brand Awareness dan Brand Image yang di miliki oleh busana muslim merek Rabbani ini masih kuat, di mata konsumen merek Rabbani masih merek yang terkenal maka ia masih mampu menciptakan daya tarik bagi konsumen, sehingga konsumen kembali datang ke outlet Rabbani untuk melakukan pembelian produk.

\section{Brand Awareness, Brand Image dan Keputusan Pembelian}

Suatu produk yang diciptakan oleh produsen pasti memiliki merek atau brand, dengan tujuan agar para target pasar atau konsumen dapat mengenal produk yang diciptakan oleh produsen tersebut. Merek merupakan titik awal suatu produk diciptakan. Merek sangat berperan penting dalam hal pengenalan akan produk tersebut kepada pihak konsumennya. Merek yang memiliki keunikan dan mudah diingat oleh para konsumen, merupakan merek yang berhasil masuk dalam benak konsumennya. Dengan kata lain merek tersebut berhasil menunjukkan eksistensinya sebagai produk yang dikenal oleh konsumen. ${ }^{7}$

Brand awareness merupakan kemampuan calon pembeli atau konsumen untuk mengenali maupun mengingat sebuah merek produk. Dalam hal ini meliputi nama,

\footnotetext{
${ }^{5} \mathrm{Ibid}, \mathrm{Hlm} 3$.

${ }^{6}$ Supriyadi, Pengaruh Kualitas Produk dan Brand image Terhadap Keputusan Pembelian (Studi pada Mahasiswa Pengguna Produk Sepatu Merek Converse di FISIP Universitas Merdeka Malang), (Malang: Universitas Merdeka Malang, 2016). Hlm. 3

${ }^{7}$ Andhini Wulan Saputri, pengaruh brand awareness, brand image dan media komunikasi terhadap keputusan pembelian pada jaringan 4G LTE PT. TELKOMSEL studi kasus mahasiswa universitas pancasila, (Jakarta: Universitas Pancasila, 2017). Hlm. 12
} 
simbol serta logo tertentu yang digunakan para pelaku pemasar untuk mempromosikan produk-produknya. ${ }^{8}$

Brand awareness adalah kesanggupan seorang calon pembeli untuk mengenali dan mengingat merek sebagai bagian dari suatu produk dengan merek yang dilibatkan. Semakin tinggi tingkat kesadaran merek (brand awareness) dalam benak konsumen, akan semakin melekat suatu merek dalam benak konsumen, sehingga makin besar kemungkinan merek tersebut dipertimbangkan dalam pembelian dan semakin besar pula kemungkinan ia akan dipilih oleh konsumen. ${ }^{9}$

Brand Image (citra merek) merupakan representasi dari keseluruhan persepsi terhadap merek dan dibentuk dari informasi dan pengalaman masa lalu terhadap merek itu. Citra terhadap merek berhubungan dengan sikap yang berupa keyakinan dan preferensi terhadap suatu merek. Konsumen yang memiliki citra yang positif terhadap suatu merek, akan lebih memungkinkan untuk melakukan pembelian. ${ }^{10}$

Brand image (citra merek) dapat dianggap sebagai jenis asosiasi yang muncul di benak konsumen ketika mengingat sebuah merek tertentu. Asosiasi tersebut secara sederhana dapat muncul dalam bentuk pemikiran atau citra tertentu yang dikaitkan kepada suatu merek, sama halnya ketika kita berfikir tentang orang lain. Asosiasi ini dapat dikonseptualisasi berdasarkan: jenis, dukungan, kekuatan, dan keunikan. ${ }^{11}$

Keputusan pembelian adalah suatu tindakan atau prilaku konsumen jadi atau tidaknya melakukan suatu pembelian atau transaksi, banyak tidaknya jumlah konsumen dalam mengambil keputusan menjadi salah satu penentu tercapai atau tidaknya tujuan perusahaan. ${ }^{12}$

Keputusan pembelian merupakan perilaku seseorang dalam menentukan suatu pilihan produk untuk mencapai kepuasan sesuai kebutuhan dan keinginan konsumen yang meliputi pengenalan masalah, pencarian informasi, evaluasi terhadap alternatif pembelian, keputusan pembelian dan perilaku setelah pembelian. ${ }^{13}$

Proses keputusan pembelian terdiri dari lima tahap yang dilakukan oleh seorang konsumen sebelum sampai pada keputusan pembelian dan selanjutnya pasca pembelian. Keputusan pembelian yang dilakukan oleh konsumen dapat terjadi apabila konsumen merasakan adanya kepuasan dan ketidakpastian, maka dari itu konsepkonsep keputusan pembelian tidak lepas dari konsep kepuasan pelanggan. Secara umum manusia bertindak rasional dan mempertimbangkan segala jenis informasi

\footnotetext{
${ }^{8}$ Iva Hidayatika, Pengaruh Kualitas Produk dan Brand Awareness Terhadap Keputusan Pembelian produk Rabbani di Toko Asya Darussalam Semarang, (Semarang, UIN Walisongo Semarang, 2015).Hlm. 24

${ }^{9}$ Febrian Andrologi, analisis pengaruh brand image dan brand awareness terhadap brand loyality dan dampaknya dan dampaknya terhadap brand equity, (Semarang: Universitas Diponegoro, 2014). Hlm. 17

${ }^{10}$ Matias Gadau, pengaruh citra merek (brand image) terhadap loyalitas konsumen, (Yogyakarta: Universitas Sanata Dharma, 2016). Hlm. 22

${ }^{11}$ Gregorius Klemencino Baha, analisis pengaruh brand image, harga, fasilitas dan kualitas terhadap perilaku konsumen dalam membeli sebuah produk, (Yogyakarta: Universitas Sanata Dharma, 2017). Hlm. 33

${ }^{12}$ Bagas Rifki Wicaksono, pengaruh kualitas produk terhadap keputusan pembelian layanan internet yang dimediasi oleh minat membeli, (Yogyakarta: Universitas Negeri Yogyakarta, 2016). Hlm. 19

${ }^{13}$ Mujiroh, pengaruh produk, pelayanan, dan lokasi terhadap keputusan pembelian konsumen pada pasar swalayan indo risky purbalingga, (Semarang: Universitas Negeri Semarang 2005). Hlm. 12
} 
yang tersedia dan mempertimbangkan segala sesuatau yang mungkin bisa muncul dari tindakannya sebelum melakukan sebuah perilaku tertentu.

Keputusan pembelian konsumen sangat dipengaruhi oleh beberapa faktor penting. Faktor-faktor ini sangat penting untuk diketahui bagi pemasar agar dapat menentukan strategi yang akan diterapkan. seperti yang telah dikemukakan oleh Philip Kotler bahwa perilaku pembelian konsumen dipengaruhi oleh faktor-faktor budaya, sosial, pribadi, dan psikologis. ${ }^{14}$

Pendekatan yang digunakan dalam penelitian ini adalah pendekatan kuantitatif deskriptif. Metode kuantitatif adalah data dalam penelitian berupa angkaangka dan menggunakan analisis statistik. ${ }^{15}$ Sementara metode deskriptif adalah mendeskriptifkan atau menggambarkan data yang telah terkumpul sebagaimana adanya tanpa bermaksud membuat kesimpulan yang berlaku untuk umum atau

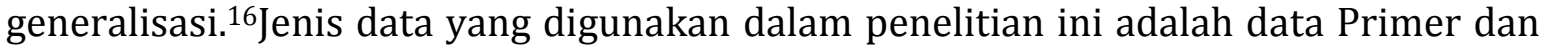
data sekunder. Data primer diperoleh secara langsung dalam bentuk persepsi atau jawaban responden (sampel) penelitian yang diperoleh melalui penyebaran kuesioner dengan konsumen Rabbani di Kota Jambi.Data sekunder yang digunakan dalam penelitian ini berupa studi kepustakaan baik berupa buku, jurnal-jurnal dan dokumen lainnya yang terdapat kaitannya dengan materi kajian.Instrumen Pengumpulan Data adalah melalui Kuesioner, dokumentasi, wawancara dan observasi.

Kuesioner adalah pengumpulan data dengan cara menggunakan daftar pertanyaan yang diajukan kepada responden untuk di jawab dengan memberikan kuesioner. ${ }^{17}$ Jenis kuesioner yang digunakan bersifat terbuka, yang disajikan dalam bentuk pertanyaan-pertanyaan, sehingga responden diminta untuk memilih satu jawaban yang sesuai dengan memberikan tanda checklist $(\sqrt{ }) .{ }^{18}$

Dokumentasi merupakan teknik pengumpulan data dengan memanfaatkan data sekunder yang sudah tersedia dalam perpustakaan, dari instansi yang diteliti atau dari tempat lain yang dijamin kebenarannya. Data sekunder ini antara lain berupa dokumen-dokumen resmi seperti grafik, arsip, peta lokasi penelitian, geografis dan demografis. Sementara data yang dikumpulkan melalui sumber pustaka berupa bahan-bahan referensi atau studi pustaka, yang meliputi peraturan perundangundangan, peraturan teknis, buku-buku, artikel, dan sebagainya yang sesuai dengan masalah yang dikaji.

Sebagai metode ilmiah, observasi biasanya diartikan sebagai pengamatan dan pencatatan sistematis atas fenomena-fenomena yang diselidiki. ${ }^{19}$ Metode ini digunakan untuk melihat secara langsung keadaan lokasi penelitian serta mencatat hal-hal yang berkenaan dengan masalah penelitian.

\footnotetext{
${ }^{14}$ Kotler, Philip, Manajemen Pemasaran,Analisis Perencanaan, Implementasi dan Pengendalian (terjemahan Jaka Wasana) Edisi Kesembilan, (Jakarta: Salemba Empat, 2002). Hlm 66

${ }^{15}$ Sugiyono, Peneltian Kuantitatif, Kualitatif dan R\&D, (Bandung: Alfabeta, 2012). Hlm. 7

${ }^{16}$ Usman Husaini dan Akbar Setiady Purnomo, Pengantar Statistika, (Jakarta: PT. Bumi Aksara, 2008). Hlm. 3

${ }^{17}$ Danang Sunyoto, Metode Penelitian Akuntansi, (Bandung: PT. Refika Aditama, 2013). Hlm. 23

${ }^{18}$ Sugiyono, Metode Penelitian Manajemen, (Bandung: PT. Alfabeta, 2015). Hlm 168

${ }^{19}$ Sutrisno Hadi, Metodologi Riset, (Yogyakarta: Pustaka Pelajar, 2015). Hlm. 185
} 
Wawancara dapat dipandang sebagai metode pengumpulan data dengan jalan tanya jawab sepihak yang dikerjakan dengan sistematis dan berlandaskan kepada tujuan penyelidikan. Pada umumnya dua orang atau lebih, biasanya hadir secara fisik dalam proses tanya jawab itu dan masing-masing pihak dapat menggunakan saluransaluran komunikasi secara wajar dan lancar. ${ }^{20}$

Populasi dalam penelitian ini adalah konsumen busana muslim merek Rabbani di Kota Jambi yang sudah pernah atau sudah beberapa kali membeli busana muslim merek Rabbani. Dalam penelitian ini menggunakan populasi tidak terbatas karena sumber data yang diperoleh itu jumlah populasinya tidak dapat dihitung dan namanama populasinya tidak diketahui.Penentuan sampel dalam penelitian ini menggunakan nonprobability sampling, yaituteknik sampling yang memberikan peluang yang sama pada setiap unsur atau anggota populasi untuk dipilih menjadi sampel. Dengan metode pengambilan sampel yang digunakan adalah insidental sampling, yaitu teknik penentuan sampel berdasarkan kebetulan, yaitu siapa saja yang secara kebetulan bertemu dengan peneliti dapat digunakan sebagai sampel, bila dipandang orang yang kebetulan ditemui itu cocok sebagai sumber data. ${ }^{21}$ Sampel dalam penelitian ini berjuamlah 100 .

1. Uji Validitas Instrumen

Variabel Brand Awareness ( $\left.\mathrm{X}_{1}\right)$ Hasil Uji Validitas Brand Awareness ( $\mathrm{X}_{1}$ )

\begin{tabular}{|l|l|l|l|}
\hline $\begin{array}{l}\text { Item } \\
\text { Pertanyaan }\end{array}$ & $\mathrm{R}_{\text {hitung }}$ & $\mathrm{R}_{\text {tabel }}$ & Keterangan \\
\hline 1 & 0,759 & 0,196 & Valid \\
\hline 2 & 0,541 & 0,196 & Valid \\
\hline 3 & 0,680 & 0,196 & Valid \\
\hline 4 & 0,741 & 0,196 & Valid \\
\hline 5 & 0,661 & 0,196 & Valid \\
\hline
\end{tabular}

Sumber: Hasil Olah Data

Berdasarkan hasil pengujian pada tabel 4.5 setiap item pertanyaan

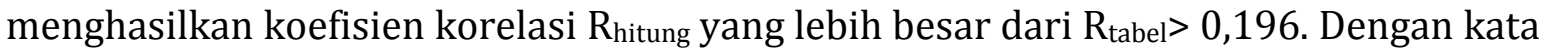
lain, instrumen penelitian yang berjumlah 5 pertanyaan untuk variabel brand awareness $\left(\mathrm{X}_{1}\right)$ dinilai semua butir pertanyaan adalah valid.

\footnotetext{
${ }^{20}$ Sutrisno Hadi, Metodologi Riset, (Yogyakarta: Pustaka Pelajar, 2015). Hlm. 264

21 Sujarweni, Wiratna, Metodologi Penelitian Bisnis dan Ekonomi, (Yogyakarta: PT. Pustaka Baru, 2015). Hlm 87-88.
} 
Variabel Brand Image $\left(\mathrm{X}_{2}\right)$ Hasil Uji Validitas Brand Image $\left(\mathrm{X}_{2}\right)$

\begin{tabular}{|l|l|l|l|}
\hline $\begin{array}{l}\text { Item } \\
\text { Pertanyaan }\end{array}$ & $\mathrm{R}_{\text {hitung }}$ & $\mathrm{R}_{\text {tabel }}$ & Keterangan \\
\hline 1 & 0,699 & 0,196 & Valid \\
\hline 2 & 0,321 & 0,196 & Valid \\
\hline 3 & 0,642 & 0,196 & Valid \\
\hline 4 & 0,697 & 0,196 & Valid \\
\hline 5 & 0,612 & 0,196 & Valid \\
\hline
\end{tabular}

Sumber: Hasil Olah Data

Berdasarkan hasil pengujian pada tabel 4.6 setiap item pertanyaan

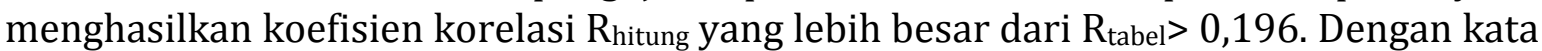
lain, instrumen penelitian yang berjumlah 5 pertanyaan untuk variabel brand image $\left(\mathrm{X}_{2}\right)$ dinilai semua butir pertanyaan adalah valid.

Variabel Keputusan Pembelian (Y)

Hasil Uji Validitas Keputusan Pembelian

\begin{tabular}{|c|l|l|l|}
\hline $\begin{array}{c}\text { Item } \\
\text { Pertanyaan }\end{array}$ & $\mathrm{R}_{\text {hitung }}$ & $\mathrm{R}_{\text {tabel }}$ & Keterangan \\
\hline 1 & 0,395 & 0,196 & Valid \\
\hline 2 & 0,640 & 0,196 & Valid \\
\hline 3 & 0,767 & 0,196 & Valid \\
\hline 4 & 0,749 & 0,196 & Valid \\
\hline 5 & 0,620 & 0,196 & Valid \\
\hline
\end{tabular}

Sumber: Hasil Olah Data

Berdasarkan hasil pengujian pada tabel 4.7 setiap item pertanyaan

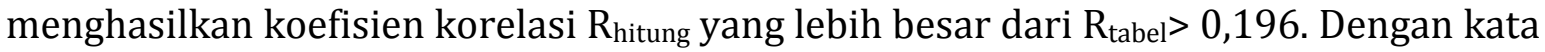
lain, instrumen penelitian yang berjumlah 5 pertanyaan untuk variabel keputusan pembelian (Y) dinilai semua butir pertanyaan adalah valid.

2. Uji Reliabilitas Variabel

Hasil Uji Reliabilitas Brand Awareness

Reliability Statistics

\begin{tabular}{|c|c|c|}
\hline Cronbach's Alpha & $\mathrm{N}$ of Items \\
\hline
\end{tabular}

, 767

6

Sumber: Hasil Olah Data 
Hasil pengujian terhadap reliabilitas kuesioner menghasilkan angka cronboach Alpha sebesar 0,767. Hal ini dapat dinyatakan bahwa semua pertanyaan dari variabel brand awareness $\left(\mathrm{X}_{1}\right)$ teruji reliabilitas sehingga dinyatakan reliable.

\section{Hasil Uji Reliabilitas Brand Image}

Reliability Statistics

\begin{tabular}{|l|l|}
\hline Cronbach's Alpha & N of Items \\
\hline
\end{tabular}

\begin{tabular}{l|l}
\hline, 733 & 6 \\
\hline
\end{tabular}

\section{Sumber: Hasil Olah Data}

Hasil pengujian terhadap reliabilitas kuesioner menghasilkan angka cronboach Alpha sebesar 0,733. Hal ini dapat dinyatakan bahwa semua pertanyaan dari variabel brand image $\left(\mathrm{X}_{2}\right)$ teruji reliabilitas sehingga dinyatakan reliable.

Hasil Uji Reliabilitas Keputusan Pembelian

Reliability Statistics

\begin{tabular}{|l|l|}
\hline $\begin{array}{l}\text { Cronbach's } \\
\text { Alpha }\end{array}$ & N of Items \\
\hline, 753 & 6 \\
\hline
\end{tabular}

Sumber: Hasil Olah Data

Hasil pengujian terhadap reliabilitas kuesioner menghasilkan angka cronboach Alpha sebesar 0,753. Hal ini dapat dinyatakan bahwa semua pertanyaan dari variabel keputusan pembelian $(\mathrm{Y})$ teruji reliabilitas sehingga dinyatakan reliable.

3. Analisis Uji Asumsi Klasik

a. Uji Normalitas

Hasil Uji Normalitas-Kolmogorov Smirnov

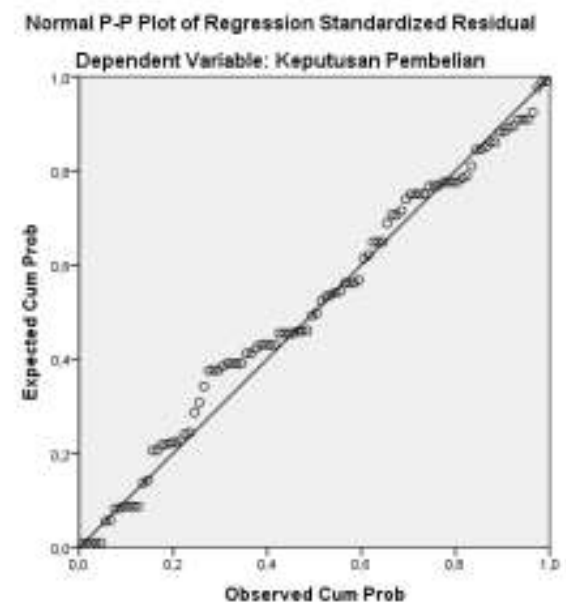


Berdasarkan gambar grafik normal probability plot dapat diketahui bahwa sebaran titik-titik disekitar garis diagonal, yang berarti data tersebut berdistribusi normal sehingga model regresi dapat dipakai untuk prediksi probability berdasarkan masukan variabel independen.

b. Uji Multikolinieritas Hasil Uji Multikolinieritas

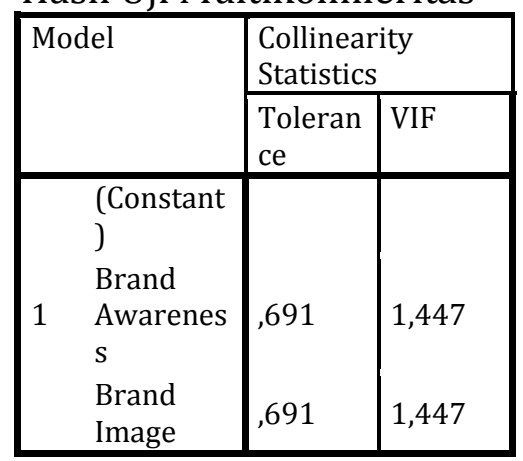

Sumber: Hasil Olah Data

Dari hasil penelitian pada tabel 4.12 terlihat bahwa nilai tolerance dan VIF menunjukkan bahwa tidak ada satu variabel independen yang memiliki nilai VIF lebih besar dari 10 dan tidak ada satu nilai tolerance variabel independen yang memenuhi nilai tolerance yaitu kurang dari 0,1 yang berati tidak terjadi multikolinieritas.

c. Uji Heteroskedastisitas

Scatterplot

Dependen variabel: Keputusan Pembelian

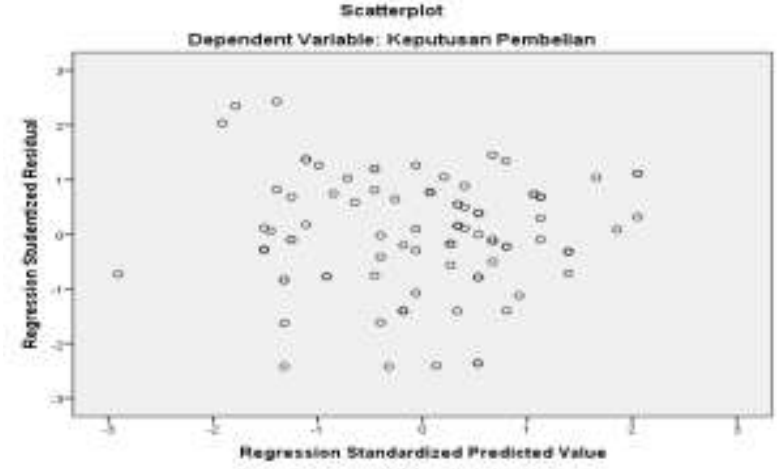

Berdasarkan gambar scatterplot di atas dapat diketahui bahwa gambar atau titik di atas menyebar dan titik tidak membentuk suatu garis atu pola tertentu. Berarti tidak terdapat heteroskedastisitas dalam model ini, dengan kata lain semua variabel independen yang terdapat dalam model ini memiliki sebaran varian yang sama atau homogen. 
4. Analisis Uji Hipotesis

a. Hasil Analisis Regresi Linier Berganda

Hasil Uji Regresi Linear Berganda

Coefficients ${ }^{\mathrm{a}}$

\begin{tabular}{|c|l|l|l|l|l|}
\hline Model & \multicolumn{2}{|l|}{ Unstandardized } \\
Coefficients & $\begin{array}{l}\text { Standar } \\
\text { dized } \\
\text { Coeffici } \\
\text { ents }\end{array}$ & T & Sig. \\
\cline { 2 - 5 } & B & $\begin{array}{l}\text { Std. } \\
\text { Error }\end{array}$ & Beta & & \\
\hline $\begin{array}{l}\text { (Constant } \\
\text { J } \\
\text { Brand } \\
\text { Awarenes } \\
\text { s } \\
\text { Brand } \\
\text { Image }\end{array}$ & 4,849 & 1,637 & & $\begin{array}{l}2,96 \\
2\end{array}$ &, 004 \\
\hline
\end{tabular}

a. Dependent Variable: Keputusan Pembelian

$\mathrm{Y}=\mathrm{a}+\mathrm{b}_{1} \mathrm{X}_{1}+\mathrm{b}_{2} \mathrm{X}_{2}+\mathrm{e}$

$\mathrm{Y}=4,849+0,281\left(\mathrm{X}_{1}\right)+0,414\left(\mathrm{X}_{2}\right)+\mathrm{e}$

Persamaan regresi linier tersebut dapat di interprestasikan sebagai berikut:

1) Nilai konstanta $(\alpha)$ sebesar 4,849 menunjukkan bahwa jika variabel brand awareness dan brand image dianggap konstan atau sama dengan nol (0) terhadap keputusan pembelian adalah sebesar 4,849.

2) Koefisien regresi brand awareness $\left(\mathrm{X}_{1}\right)$ sebesar 0,281 menyatakan bahwa setiap kenaikan skor variabel brand awareness dengan asumsi variabel lain dianggap konstan maka skor variabel keputusan pembelian akan naik sebesar 0,281 .

3) Koefisien regresi brand image $\left(\mathrm{X}_{2}\right)$ sebesar 0,414 menyatakan bahwa setiap kenaikan skor variabel brand image dengan asumsi variabel lain dianggap konstan maka skor variabel keputusan pembelian akan naik sebesar 0,414.

b. Uji T

Hasil Uji T

Coefficients $^{\mathrm{a}}$

\begin{tabular}{|c|c|c|c|c|c|c|}
\hline \multirow{2}{*}{\multicolumn{2}{|c|}{ Model }} & \multicolumn{2}{|c|}{$\begin{array}{l}\text { Unstandardized } \\
\text { Coefficients }\end{array}$} & \multirow{2}{*}{\begin{tabular}{|l} 
Standar \\
dized \\
Coeffici \\
ents \\
Beta
\end{tabular}} & \multirow[t]{2}{*}{$\mathrm{T}$} & \multirow[t]{2}{*}{ Sig. } \\
\hline & & B & $\begin{array}{l}\text { Std. } \\
\text { Error }\end{array}$ & & & \\
\hline \multirow{3}{*}{1} & $\begin{array}{l}\text { (Constant } \\
\text { ) }\end{array}$ & 4,849 & 1,637 & & $\begin{array}{l}2,96 \\
2\end{array}$ & ,004 \\
\hline & $\begin{array}{l}\text { Brand } \\
\text { Awarenes } \\
\text { s }\end{array}$ & 281 & ,090 & 294 & $\begin{array}{l}3,11 \\
7\end{array}$ & ,002 \\
\hline & $\begin{array}{l}\text { Brand } \\
\text { Image }\end{array}$ & , 414 & ,092 & 423 & $\begin{array}{l}4,48 \\
7\end{array}$ & ,000 \\
\hline
\end{tabular}

a. Dependent Variable: Keputusan Pembelian 
Dari hasil uji $\mathrm{T}$ yang dikemukakan pada tabel 4.15 maka dapat diinterpretasikan pengaruh masing-masing variabel independen (brand awareness dan brand image) terhadap variabel dependen (keputusan pembelian), sebagai berikut:

1. Hipotesis yang pertama bahwa varibel brand awareness $\left(\mathrm{X}_{1}\right)$ berpengaruh signifikan terhadap keputusan pembelian (Y). berdasarkan hasil analisis uji T diperoleh besarnya $t_{\text {hitung }}$ untuk variabel brand awareness $\left(\mathrm{X}_{1}\right)$ sebesar 3,117 dengan $t_{\text {tabel }}=1,984$ maka nilai $t_{\text {hitung }}>t_{\text {tabel }}$ sementara nilai signifikan $t_{\text {hitung }}$ variabel brand awareness $\left(\mathrm{X}_{1}\right)$ sebesar 0,002 maka signifikansi thitung $<0,05$ berdasarkan hasil tersebut maka Ho ditolak dan Ha diterima yang berarti variabel brand awareness $\left(\mathrm{X}_{1}\right)$ berpengaruh secara signifikan terhadap keputusan pembelian (Y).

2. Hipotesis kedua bahwa variabel brand image $\left(\mathrm{X}_{2}\right)$ berpengaruh signifikan terhadap keputusan pembelian (Y). berdasarkan hasil analisis uji T diperoleh besarnya thitung untuk variabel brand image $\left(\mathrm{X}_{2}\right)$ sebesar 4,487 dengan $\mathrm{t}_{\text {tabel }}=$ 1,984 maka nilai $t_{\text {hitung }}>t_{\text {tabel }}$ sementara nilai signifikan thitung variabel brand image $\left(\mathrm{X}_{2}\right)$ sebesar 0,000 maka signifikansi $t_{\text {hitung }}<0,05$ berdasarkan hasil tersebut maka Ho ditolak dan Ha diterima yang berarti variabel brand image $\left(\mathrm{X}_{2}\right)$ berpengaruh secara signifikan terhadap keputusan pembelian (Y).

c. Uji F

Hasil Uji F

ANOVAa $^{a}$

\begin{tabular}{|ll|l|l|l|l|l|}
\hline \multicolumn{2}{|l|}{ Model } & $\begin{array}{l}\text { Sum of } \\
\text { Squares }\end{array}$ & Df & $\begin{array}{l}\text { Mean } \\
\text { Square }\end{array}$ & F & Sig. \\
\hline \multirow{4}{*}{$\begin{array}{l}\text { Regressi } \\
\text { on }\end{array}$} & 437,616 & 2 & 218,808 & 32,846 &, $000^{\mathrm{b}}$ \\
& $\begin{array}{l}\text { Residual } \\
\text { Total }\end{array}$ & 646,174 & 97 & 6,662 & & \\
\hline
\end{tabular}

a. Dependent Variable: Keputusan Pembelian

b. Predictors: (Constant), Brand Image, Brand Awareness

Dari hasil uji F yang dikemukakan pada tabel 4.16 maka dapat diinterpretasikan hasil uji $\mathrm{F}$ yaitu brand awareness dan brand image secara bersamaan berpengaruh signifikan terhadap keputusan pembelian karena nilai $F_{\text {hitung }}>F_{\text {tabel }}$ atau 32,846 > 2,70 dan nilai signifikan yang dihasilkan 0,000 lebih kecil dari level of significant 0,05. Keputusan hipotesisnya adalah variabel brand awareness dan brand image secara bersam-sama berpengaruh signifikan terhadap keputusan pembelian sehingga Ha diterima Ho ditolak. 
d. Uji Koefisien Determinasi ( $\mathrm{R}$ - Square)

Hasil Uji R - Square

Model Summaryb

\begin{tabular}{|l|l|l|l|l|}
\hline Model & $\mathrm{R}$ & R Square & $\begin{array}{l}\text { Adjusted } \\
\text { Square }\end{array}$ & $\begin{array}{l}\text { Std. Error of } \\
\text { the Estimate }\end{array}$ \\
\hline 1 &, $635^{\mathrm{a}}$ &, 404 &, 391 & 2,581 \\
\hline
\end{tabular}

a. Predictors: (Constant), Brand Image, Brand Awareness

b. Dependent Variable: Keputusan Pembelian

Berdasarkan tabel diatas diperoleh besarnya Adjusted $R$ square $\left(\mathrm{R}^{2}\right)$ adalah 0,391. Hasil ini menunjukkan bahwa 39,1\% menunjukkan bahwa variabel brand awareness $\left(\mathrm{X}_{1}\right)$ dan brand image $\left(\mathrm{X}_{2}\right)$ terhadap variabel keputusan pembelian $(\mathrm{Y})$ sebesar 39,1\%. Sedangkan sisanya 60,9\% nilai keputusan pembelian dipengaruhi oleh variabel lain yang tidak diteliti dalam penelitian ini.

\section{Pengaruh Brand Awareness terhadap Keputusan Pembelian}

Pernyataan hipotesis pertama $\left(\mathrm{H}_{1}\right)$ dapat diterima, maka brand awareness berpengaruh positif dan signifikan terhadap keputusan pembelian. Kondisi tersebut dapat dilihat dari hasil pengujian yang dilakukan berdasarkan analisis SPSS dari kuesioner yang diisi oleh para responden yang menyatakan brand awareness tergolong baik yang meliputi 4 indikator yaitu : (1) Merek mudah di ingat, artinya elemen merek yang dipilih mudah di ingat dan disebut atau diucapkan. Simbol, logo, nama yang digunakan menarik, unik sehingga menarik perhatian masyarakat untuk di ingat dan dikonsumsi. (2) Mempunyai pengetahuan tentang merek, artinya masyarakat sudah mengenal dan mengetahui tentang merek tersebut, mengetahui berbagai produk-produk yang di produksi oleh merek tersebut. (3) Dapat membedakan dengan merek lain, artinya ciri khas merek tersebut berbeda dengan merek lainnya atau mempunyai ciri khas tersendiri sehingga masyarakat mudah untuk mengenali dan mengingat merek tersebut. (4) Dapat mengenali logo atau simbol merek, artinya dengan hanya melihat logo atau simbol merek yang muncul di media masa atau media elektronik atau dengan melihat langsung, masyarakat dapat mengenali bahwa logo atau simbol merek tersebut adalah merek yang dimaksudkan.

Dalam hal ini, maka tercipta hasil yang diperoleh nilai thitung untuk variabel brand awareness sebesar 3,117 dengan nilai signifikansi sebesar 0,002 lebih kecil dari 0,05 serta nilai koefisien brand awareness 0,281 yang menyatakan bahwa brand awarenessberpengaruh positif dan signifikan terhadap keputusan pembelian. Hal ini berarti jika brand awarenessatas suatu merek produk akan memiliki peranan dalam membantu konsumen memutuskan cara memperoleh manfaat atau kegunaan tertinggi yang diharapkan dari produk tersebut. Dengan demikian brand awarenessakan menciptakan peluang terbesar bagi seseorang untuk memilih suatu merek produk. Hasil penelitian ini didukung oleh penelitan Iva Hidayatika (2015) 
dengan judul skripsi Pengaruh Kualitas Produk dan Brand Awareness Terhadap Keputusan Pembelian Produk Rabbani di Toko Asya Darussalam Semarang. Hasil penelitian tersebut menunjukkan bahwa brand awareness mempunyai hubungan positif dan signifikan terhadap keputusan pembelian.

\section{Pengaruh Brand Image Terhadap Keputusan Pembelian}

Pernyataan hipotesis kedua $\left(\mathrm{H}_{2}\right)$ dapat diterima, maka brand image berpengaruh positif dan signifikan terhadap keputusan pembelian. Kondisi tersebut dapat dilihat dari hasil pengujian yang dilakukan berdasarkan analisis SPSS dari kuesioner yang diisi oleh para responden yang menyatakan brand image tergolong baik yang meliputi 3 indikator yaitu : (1) Citra pembuat/perusahaan, yaitu kesan secara umum yang tertinggal di benak konsumen sebagai hasil dari kumpulan perasaan, ide, sikap dan pengalaman dengan perusahaan yang disimpan dalam ingatan. Kesan tersebut kemudian diubah bentuknya menjadi citra positif atau negatif sesuai dengan perasaan dan pengalaman konsumen pada perusahaan, baik citra positif maupun negatif kemudian akan teringat kembali ketika nama perusahaan tersebut terdengar atau terbawa ke dalam ingatan konsumen. (2) Citra pemakai, yaitu sekumpulan asosiasi yang dipersepsikan konsumen terhadap pemakai yang menggunakan barang atau jasa, meliputi pemakai itu sendiri, gaya hidup atau kepribadian dan status sosial. (3) Citra produk, yaitu sekumpulan asosiasi yang dipersepsikan konsumen terhadap suatu produk, yang meliputi atribut produk tersebut, manfaat bagi konsumen, penggunaannya, serta jaminan.

Dalam hal ini, maka tercipta hasil yang diperoleh nilai thitung untuk variabel brand image sebesar 4,487 dengan nilai signifikansi sebesar 0,000 lebih kecil dari 0,05 serta nilai koefisien brand image 0,414 yang menyatakan bahwa brand image berpengaruh positif dan signifikan terhadap keputusan pembelian. Variabel ini merupakan interprestasi yang diakumulasikan ke berbagai informasi yang dapat diterima oleh konsumen. Hal ini berarti apabila tingkat brand image tinggi maka kesediaan konsumen dalam membeli produk akan tinggi pula. Pernyataan yang mendukung penelitian secara parsial antara brand image terhadap keputusan pembelian adalah responden cenderung membeli produk atau jasa yang sudah dikenal baik oleh pelanggan atau konsumen itu sendiri, dibandingkan dengan produk atau jasa yang baru diciptakan oleh pihak produsen atau perusahaan, dikarenakan produk yang dikenal memiliki jaminan yang mendorong seorang konsumen lebih nyaman dalam mengkonsumsi produk. Hasil penelitian ini didukung oleh penelitan Eza Aprilia Sari (2015) dengan judul skripsi Analisis Pengaruh Brand Image dan Kualitas Produk Terhadap Keputusan Pembelian dan Kepuasan Konsumen Rabbani di Pekanbaru. Hasil penelitian tersebut menunjukkan bahwa brand Image mempunyai hubungan positif dan signifikan terhadap keputusan pembelian. 


\section{Penutup}

Berdasarkan hasil penelitian yang telah dilakukan, maka diperoleh kesimpulan sebagai berikut: pertama, Berdasarkan hasil Uji T (uji secara parsial) bahwa brand awareness berpengaruh positif dan signifikan terhadap keputusan pembelian karena nilai $\mathrm{f}_{\text {hitung }}>\mathrm{f}_{\text {tabel }}$ atau 3,117 $>1,984$ nilai signifikan yang dihasilkan 0,002 lebih kecil dari level of significant 0,05. Dan brand image berpengaruh positif dan signifikan terhadap keputusan pembelian karena nilai $\mathrm{f}_{\text {hitung }}>\mathrm{f}_{\text {tabel }}$ atau 4,487 $>1,984$ nilai signifikan yang dihasilkan 0,000 lebih kecil dari level of significant 0,05 .v. Kedua, berdasarkan hasil Uji F (uji secara simultan) dapat disimpulkan bahwa brand awareness dan brand image secara bersama-sama berpengaruh signifikan terhadap keputusan pembelian karena nilai $\mathrm{f}_{\text {hitung }}>\mathrm{f}_{\text {tabel }}$ atau $32,846>2,70$ nilai signifikan yang dihasilkan 0,000 lebih kecil dari level of significant 0,05. Karena $f_{\text {hitung }}>f_{\text {tabel }}$ maka hal ini berarti bahwa variabel brand awareness dan brandimage secara bersama-sama atau secara simultan berpengaruh terhadap keputusan pembelian. Dilihat dari koefisien determinasi dapat diketahui bahwa secara simultan brand awareness dan brand image berpengaruh terhadap keputusan pembelian sebesar 39,1\%. Sedangkan sisanya sebesar $60,9 \%$. Nilai keputusan pembelian dipengaruhi oleh variabel lainnya yang tidak diteliti dalam penelitian ini. 


\section{BIBLIOGRAFI}

Basuki A.T., dan Prawoto Nano, Analisis Regresi Dalam Penelitian Ekonomi \& Bisnis Dilengkapi Aplikasi Spss \& Eviews, Jakarta: Raja Grafindo Persada. 2016

Daryanto, dan Setyobudi Ismanto, Konsumen dan Pelayanan Prima, cetakan kesatu, Yogyakarta: Gava Media, 2014.

Hadi Sutrisno, Metodologi Riset, Yogyakarta: Pustaka Pelajar, 2015.

Kotler, Philip, Manajemen Pemasaran,Analisis Perencanaan, Implementasi dan Pengendalian terjemahan Jaka Wasana Edisi Kesembilan, Jakarta: Salemba Empat, 2002.

Rangkuti Freddy,The Power of Brands, Jakarta: Gramedia Pustaka Utama.

Sunyoto Danang, Metode Penelitian Akuntansi, Bandung: Refika Aditama, 2013.

Sugiyono, Metode Penelitian Kuantitatif, Kualitatif R \& D, Bandung: Alfabeta, 2012.

Sugiyono, Metode Penelitian Manajemen, Bandung: Alfabeta, 2015.

Sujarweni, Wiratna, Metodologi Penelitian Bisnis dan Ekonomi, Yogyakarta: Pustaka Baru, 2015.

Supranto JJ. Statistik Teori dan Aplikasi. Cetakan ke VI Jakarta: Erlangga, 2000.

Surakhmad Winarno. Pengantar Penelitian Ilmiah Dasar Metode Teknik. Bandung: Tarsito, 1985.

Usman Husaini dan Akbar Setiady Purnomo, Pengantar Statistika, Jakarta: Bumi Aksara, 2008.

Andhini Wulan Saputri, pengaruh brand awareness, brand image dan media komunikasi terhadap keputusan pembelian pada jaringan 4G LTE. TELKOMSEL studi kasus mahasiswa universitas pancasila, Jakarta: Universitas Pancasila, 2017.

Ayu Lestari, Pengaruh Harga dan Produk Terhadap Keputusan Membeli Produk Elzatta Studi Kasus pada Mahasiswa UIN Raden Fatah Fakultas Ekonomi dan Bisnis Islam, Palembang: UIN Raden Fatah, 2016.

Bagas Rifki Wicaksono, pengaruh kualitas produk terhadap keputusan pembelian layanan internet yang dimediasi oleh minat membeli, Yogyakarta: Universitas Negeri Yogyakarta, 2016.

Dedi nurdiansyah, pengaruh kualitas produk dan harga terhadap keputusan pembelian produk sepatu olahraga merek adidas dibandar lampung, Bandar Lampung: Universitas Lampung, 2017. 
Febrian Andrologi, analisis pengaruh brand image dan brand awareness terhadap brand loyality dan dampaknya dan dampaknya terhadap brand equity, Semarang: Universitas Diponegoro, 2014.

Gregorius Klemencino Baha, analisis pengaruh brand image, harga, fasilitas dan kualitas terhadap perilaku konsumen dalam membeli sebuah produk, Yogyakarta: Universitas Sanata Dharma, 2017.

Indra Lesmana, Pengaruh Ekuitas Merek Terhadap Keputusan Pembelian pada Rabbani Dipatiukur Bandung, Bandung: Universitas Komputer Indonesia 2014.

Matias Gadau, pengaruh citra merek brand image terhadap loyalitas konsumen, Yogyakarta: Universitas Sanata Dharma, 2016.

Mita Yuniati, aktor-Faktor yang Mempengaruhi Minat Konsumen Terhadap Produk Rabbani, Surabaya: Universitas Negeri Surabaya, 2013.

Muhammad Romadhoni, Pengaruh citra merek brand image terhadap pengambilan keputusan pembelian sepatu Nike pada mahasiswa FIK UNYYogyakarta: Universitas Negeri Yogyakarta, 2015.

Mujiroh, pengaruh produk, pelayanan, dan lokasi terhadap keputusan pembelian konsumen pada pasar swalayan indo risky purbalingga,Semarang: Universitas Negeri Semarang, 2005. 